\title{
PELAKSANAAN PENGUKURAN RANAH KOGNITIF, AFEKTIF, DAN PSIKOMOTOR PADA MATA PELAJARAN IPS KELAS III SD MUHAMMADIYAH PALANGKARAYA
}

\author{
IIN NURBUDIYANI \\ Dosen Pada Fakultas Keguruan dan Ilmu Pendidikan Universitas Muhammadiyah Palangkaraya
}

\begin{abstract}
ABSTRAK
Penelitian ini bertujuan untuk mendiskripsikan secara kuantitatif sejauh mana pelaksanaan pengukuran ranah kognitif, afektif, dan psikomotor di kelas III SD. Penelitian ini menggunakan pendekatan kuantitatif, karena pendekatan penelitian ini dapat mendiskripsikan hasil belajar kognitif, afektif dan psikomotor kedalam angka-angka sehingga mudah dianalisis datanya secara statistik. Prosedur ini juga untuk menghilangkan subjektifitas dalam hasil penelitian. Sampel dalam penelitian ini adalah seluruh siswa kelas III SD Muhammadiyah Palangkaraya, dan karena jumlah populasi kurang dari 100 orang maka seluruh siswa kelas III SD Muhammadiyah menjadi sampel penelitian. Variabel dalam penelitian ini adalah ranah kognitif, afektif dan psikomotor. Metode atau teknik pengumpulan data yaitu menggunakan metode pertanyaan atau berupa tes dan observasi. Sedangkan instrument yang digunakan dalam penelitian ini yaitu berupa tes untuk mengukur kemampuan awal atau akhir pembelajaran, dan observasi pada saat proses pembelajaran berlangsung. Langkah-langkah dan prosedur dalam menganalisis data adalah sebagai berikut: pengumpulan data, editing, koding, tabulasi data, pengujian kualitas data dan mendiskripsikan data. Dalam suatu proses pembelajaran perlu selalu diadakan penilaian atau evaluasi agar seorang guru memperoleh data kemajuan kemampuan yang dimiliki siswa-siswanya secara lengkap, penilaian juga akan bermakna ketika seorang guru tidak hanya melakukan satu atau dua kali penilaian, tetapi dilakukan sesering mungkin agar dapat memonitoring kemajuan siswa secara terus-menerus sekaligus melihat sejauh mana tujuan pembelajaran telah tercapai. Selain itu evaluasi juga harus dapat menggambarkan kemampuan siswa dalam tiga ranah, yaitu: ranah kognitif, afektif dan psikomotor. Untuk mengukur ranah kognitif menggunakan alat ukur berupa tes pilihan ganda, sedangkan untuk mengukur ranah afektif dan psikomotor menggunakan lembar observasi.
\end{abstract}

Kata kunci: pengukuran, ranah kognitif, afektif, psikomotor, pelajaran IPS kelas III.

\section{PENDAHULUAN}

Pendidikan merupakan salah satu sektor penting dalam pembangunan di setiap Negara. Pendidikan bertujuan untuk mengembangkan potensi anak agar memiliki kekuatan spiritual keagamaan, pengendalian diri, berkepribadian, memiliki kecerdasan, berakhlak mulia, serta memiliki keterampilan yang diperlukan sebagai anggota masyarakat dan warga Negara. Kondisi ideal dalam bidang pendidikan di Indonesia adalah tiap anak bisa sekolah minimal hingga tingkat SMA. Namun hal tersebut sangat sulit untuk direalisasikan pada saat ini. Oleh karena itu evaluasi pendidikan merupakan salah satu komponen utama yang tidak dapat dipisahkan ditanamkan di sekolah, bukan hanya pengetahuan kognitif saja. UAN tidak akan dapat menjawab pertanyaan seberapa jauh perkembangan anak mengenal: seni, olah raga, menyanyi, kepercayaan diri, keberanian mengemukakan pendapat dan bersikap demokratis. Dengan kata lain UAN tidak mampu menyediakan informasi yang cukup mengenai mutu pendidikan, atau tujuan yang diinginkan masih terlalu jauh untuk dicapai dengan UAN.

Selain itu ujian juga bertujuan untuk mempertanggungjawabkan penyelenggaraan pendidikan kepada masyarakat. Ironis kalau UAN dipakai sebagai bentuk pertanggung jawaban penyelenggaraan pendidikan, karena pendidikan 
merupakan satu kesatuan terpadu antara kognitif, afektif dan psikomotor. Selain itu pendidikan juga bertujuan untuk membentuk manusia yang berakhlak mulia, berbudi luhur, mandiri, cerdas, dan kreatif yang semuanya itu tdak dapat dilihat hanya dengan UAN. Artinya UAN belum memenuhi syarat untuk dipakai sebagai bentuk pertanggungjawaban penyelenggaraan pendidikan kepada masyarakat. Sebagai konsekuensinya guru harus mengembangkan system evaluasi yang dapat menjawab semua kemampuan yang dipelajari dan diperoleh selama mengikuti pendidikan. Selain itu pendidikan harus mampu membedakan antara anak yang mengikuti pendidikan dengan anak yang tidak mengikuti pendidikan. Dengan kata lain evaluasi tidak bisa dilakukan hanya pada saat tertentu, tetapi harus dilakukan secara komprehensip atau menyeluruh dengan beragam bentuk dan dilakukan secara terus menerus dan berkelanjutan. Menurut Sukardi (2010: 4), evaluasi memiliki beberapa jenis yaitu: (1) evaluasi harus masuk dalam kisikisi yang telah ditentukan; (2) evaluasi sebaiknya dilaksanakan secara komprehensip; (3) evaluasi diselenggarakan dalam proses kontinu; dan (4) evaluasi harus mempertimbangkan nilai-nilai yang berlaku. Sedangkan menurut Slameto (2001: 16), evaluasi harus mempunyai minimal tujuh prinsip yaitu: (1) terpadu; (2) menganut cara belajar siswa aktif; (3) kontinuitas; (4) koherensi dengan tujuan; (5) menyeluruh; (6) membedakan; dan (7) pedagogis.

Sesuai dengan permasalahan evaluasi yang dikemukakan di atas, maka peneliti ingin mengungkap bagaimana pelaksanaan pengukuran ranah kognitif, afektif dan psikomotor siswa kelas III SD Muhammadiyah Palangkaraya.
Dengan melaksanakan pengukuran ranah kognitif, afektif dan psikomotor diharapkan dapat menggambarkan kemampuan siswa secara utuh dan dapat dipertanggungjawabkan hasilnya.

\section{KAJIAN PUSTAKA}

\section{Pengertian Pengukuran Kognitif}

Pada umumnya hasil belajar dapat dikelompokkan menjadi tiga aspek yaitu: ranah kognitif, ranah afektif, dan ranah psikomotor, dan secara eksplisit ketiga aspek ini tidak dapat dipisahkan satu sama lain. Apapun jenis mata ajarnya selalu menggunakan tiga aspek tersebut namun memiliki penekanan yang berbeda. Untuk aspek kognitif lebih menekankan pada teori, aspek psikomotor menekankan pada praktek dan kedua aspek tersebut selalu mengandung aspek afektif. Ranah kognitif adalah ranah yang mencakup kegiatan mental (otak) seperti kemampuan berpikir, memahami, menghapal, mengaplikasi, menganalisa, mensintesa, dan kemampuan mengevaluasi. Menurut taksonomi Bloom, segala upaya yang mengukur aktifitas otak adalah termasuk dalam ranah kognitif. Dalam ranah kognitif terdapat enam jenjang proses berpikir, mulai dari jenjang terendah sampai jenjang yang paling tinggi. Keenam jenjang tersebut yaitu: pengetahuan (knowledge), pemahaman (comprehension), penerapan (application), analisis (analysis), sintesis (synthesis), dan penilaian (evaluation).

Hasil belajar kognitif adalah perubahan perilaku yang terjadi dalam kawasan kognisi, hasil belajar kognitif tidak merupakan kemampuan tunggal melainkan kemampuan yang menimbulkan perubahan perilaku dalam domain kognitif yang meliputi beberapa jenjang atau 
tingkat (Purwanto, 2010: 50). Tujuan pengukuran ranah kognitif adalah untuk mendapatkan informasi yang akurat mengenai tingkat pencapaian tujuan instruksional oleh siswa pada ranah kognitif khususnya pada tingkat hapalan pemahaman, penerapan, analisis, sintesa dan evaluasi. Manfaat pengukuran ranah kognitif adalah untuk memperbaiki mutu atau meningkatkan prestasi siswa pada ranah kognitif khususnya pada tingkat hapalan, pemahaman, penerapan, analisis, sintesa dan evaluasi.

Ranah kognitif dapat diukur melalui dua cara yaitu dengan tes subjektif dan objektif. Tes subjektif biasanya berbentuk esay (uraian), namun dalam pelaksanaannya tes ini tidak dapat mencakup seluruh materi yang akan diujikan. Oleh karena itu instrument dalam penelitian ini tidak akan menggunakan tes subjektif, melainkan menggunakan tes objektif. Hal ini memang dimaksudkan untuk mengatasi kelemahankelemahan dari tes bentuk isey (Suharsimi Arikunto, 2009: 162-164). Karena dalam penggunaan tes objektif jumlah soal yang diajukan jauh lebih banyak dari pada tes esay. Menurut Suharsimi Arikunto ada beberapa macam tes objektif diantaranya yaitu: tes benar salah, pilihan ganda, menjodohkan, dan tes isian. Diantara macam-macam tes objektif tersebut peneliti akan menggunakan tes pilihan ganda (multiple choice test). Tes pilihan ganda terdiri atas suatu keterangan atau pemberitahuan tentang suatu pengertian yang belum lengkap. Dan untuk melengkapinya harus memilih satu dari beberapa kemungkinan jawaban yang telah disediakan. Adapun kemungkinan jawaban (option) terdiri atas satu jawaban yang benar yaitu kunci jawaban dan beberapa pengecoh (distractor).

\section{Pengertian Pengukuran Afektif}

David R. Krathwohl (1974: 247), berpendapat bahwa ranah afektif adalah ranah yang berkaitan dengan sikap dan nilai. Beberapa pakar mengatakan bahwa sikap seseorang dapat diramalkan perubahannya jika seseorang telah memiliki penguasaan kognitif tingkat tinggi. Cirriciri hasil belajar afektif tampak pada siswa dalam berbagai tingkah laku seperti: perhatian terhadap mata pelajaran, kedisiplinan dalam mengikuti proses belajar, motivasinya dalam belajar, penghargaan atau rasa hormatterhadap guru, dan sebagainya (Anas Sudjono, 2006: 54). Krathwohl dan kawan-kawan (1974), mengelompokkan ranah afektif ini menjadi lima jenjang yaitu: (1) menerima atau memperhatikan (receiving); (2) menanggapi (responding); (3) menailai atau menghargai (valuing); (4) mengatur atau mengorganisasikan (organization); dan (5) karakterisasi dengan suatu nilai atau kelompok nilai (characterization). Ada lima tipe karakteristik afektif yang penting yaitu: sikap, minat, konsep diri, nilai dan moral (Depdiknas, 2008: 4).

Tujuan pengukuran ranah afektif selain untuk mendapatkan informasi yang akurat mengenai tingkat pencapaian tujuan instruksional oleh siswa pada ranah afektif khususnya pada tingkat penerimaan, partisipasi, penilaian, organisasi dan internalisasi juga dapat mengarahkan peserta didik agar senang membaca buku, bekerja sama, menempatkan siswa dalam situasi belajar-mengajar yang tepat, sesuai dengan tingkat pencapaian dan kemampuan serta karakteristik siswa. Manfaat dari pengukuran ranah afekitif adalah untuk 
memperbaiki pencapaian tujuan instruksional oleh siswa pada ranah afektif khususnya pada tingkat penerimaan, partisipasi, penilaian, organisasi dan internalisasi selain itu juga dapat memperbaiki sikap, minat, konsep diri, nilai dan moral siswa.

Instrumen yang digunakan dalam pengukuran ranah afektif adalah berupa observasi, sebab observasi dalam pengambilan datanya tidak terbatas pada orang saja, tetapi juga dapat digunakan pada alam sekitar atau lingkungan alam. Observasi yaitu kegiatan pemusatan perhatian terhadap suatu objek dengan menggunakan seluruh alat indera. Menurut Sutrisno Hadi (2004: 158-168), ada tiga jenis pokok dalam observasi yang masing-masing umumnya cocok untuk keadaan-keadaan tertentu, yaitu: observasi partisipan, observasi sistematis, dan observasi eksperimental. Dari ketiga jenis observasi ini, peneliti akan menggunakan observasi sistematis, karena observasi sistematis dilakukan dengan menggunakan pedoman sebagai instrumen pengamatan. Masih menurut Sutrisno Hadi (2005: 169-173), ada beberapa macam alat observasi yang dapat digunakan dalam situasi-situasi berbeda, beberapa diantaranya adalah: Anecdotal Records, Catatan Berkala, Check Lists, Rating Scale, Mechanical Devices. Dari beberapa macam alat observasi ini, peneliti akan menggunakan observasi tipe rating scale, karena rating scale lebih fleksibel, tidak terbatas untuk pengukur sikap saja tetapi untuk mengukur persepsi responden terhadap fenomena lainnya, seperti skala untuk mengukur status sosial ekonomi, kelembagaan, kemampuan, pengetahuan, proses kegiatan dan lain-lain.

\section{Pengertian Pengukuran Psikomotor}

Ranah psikomotor adalah ranah yang berkaitan dengan keterampilan (Skill) atau kemampuan bertindak setelah seseorang menerima pengalaman belajar tertentu. Menurut Singer (1972), mata ajar yang termasuk kelompok mata ajar psikomotor adalah mata ajar yang lebih berorientasi pada gerakan dan menekankan pada reaksi-reaksi fisik. Menurut Ryan (1980: 3), penilaian hasil belajar psikomotor dapat dilakukan dengan tiga cara yaitu: melalui pengamatan langsung selama proses belajar-mengajar (persiapan), setelah proses belajar (proses), dan beberapa waktu setelah selesai proses belajarmengajar (produk). Tujuan pengukuran ranah psikomotor adalah selain untuk memperbaiki pencapaian tujuan instruksional oleh siswa pada ranah psikomotor khususnya pada tingkat imitasi, manipulasi presisi, artikulasi, dan naturalisasi, juga dapat meningkatkan kemampuan gerak reflex, gerak dasar, keterampilan perseptual, keterampilan fisik, gerak terampil, dan komunikasi non-diskusif siswa. Sedangkan manfaat dari ranah psikomotor adalah selain untuk memperbaiki pencapaian tujuan instruksional oleh siswa pada ranah psikomotor khususnya pada tingkat imitasi, manipulasi, presisi, artikulasi, dan naturalisasi juga dapat meningkatkan kemampuan gerak refleks, gerak dasar, keterampilan perseptual, keterampilan fisik, gerak terampil, dan komunikasi non-diskusif siswa.

Penilaian hasil belajar psikomotor dalam penelitian ini, dapat dilakukan dengan menggunakan pengamatan langsung serta penilaian tingkah laku siswa dalam proses belajarmengajar, dan alat yang digunakan dalam pengukuran ranah psikomotor berupa observasi. 
Observasi merupakan teknik pengumpulan data yang memiliki ciri spesifik bila dibandingkan dengan teknik wawancara dan kuesioner. Kalau wawancara dan kuesioner selalu berkomunikasi dengan orang, maka observasi tidak terbatas pada orang, tetapi juga pada objek-objek alam yang lain. Teknik pengumpulan data dengan observasi digunakan jika peneliti berkenaan dengan perilaku manusia, proses kerja, gejalagejala alam, dan bila jumlah responden tidak terlalu besar (Sugiyono, 2009: 203). Dalam penelitian ini akan digunakan observasi tipe rating scale, karena dalam rating scale lebih fleksibel, tidak terbatas untuk pengukuran sikap saja tetapi untuk mengukur status sosial, ekonomi, kelembagaan, pengetahuan, kemampuan, proses kegiatan dan lain-lain.

\section{PEMBAHASAN}

Penelitian ini menggunakan pendekatan kuantitatif, karena pendekatan penelitian ini dapat mendiskripsikan hasil belajar kognitif, afektif dan psikomotor kedalam angka-angka sehingga mudah dianalisis datanya secara statistik. Prosedur ini juga untuk menghilangkan subjektifitas dalam hasil penelitian. Sampel dalam penelitian ini adalah seluruh siswa kelas III SD Muhammadiyah Palangkaraya, dan karena jumlah populasi kurang dari 100 orang maka seluruh siswa kelas III SD Muhammadiyah menjadi sampel penelitian. Variabel dalam penelitian ini adalah ranah kognitif, afektif dan psikomotor. Metode atau teknik pengumpulan data yaitu menggunakan metode pertanyaan atau berupa tes dan observasi. Sedangkan instrument yang digunakan dalam penelitian ini yaitu berupa tes untuk mengukur kemampuan awal atau akhir pembelajaran, dan observasi pada saat proses pembelajaran berlangsung. Langkah-langkah dan prosedur dalam menganalisis data adalah sebagai berikut: pengumpulan data, editing, koding, tabulasi data, pengujian kualitas data dan mendiskripsikan data.

\section{KESIMPULAN}

Dalam suatu proses pembelajaran perlu selalu diadakan penilaian atau evaluasi agar seorang guru memperoleh data kemajuan kemampuan yang dimiliki siswa-siswanya secara lengkap, penilaian juga akan bermakna ketika seorang guru tidak hanya melakukan satu atau dua kali penilaian, tetapi dilakukan sesering mungkin agar dapat memonitoring kemajuan siswa secara terus-menerus sekaligus melihat sejauh mana tujuan pembelajaran telah tercapai. Selain itu evaluasi juga harus dapat menggambarkan kemampuan siswa dalam tiga ranah, yaitu: ranah kognitif, afektif dan psikomotor. Untuk mengukur ranah kognitif menggunakan alat ukur berupa tes pilihan ganda, sedangkan untuk mengukur ranah afektif dan psikomotor menggunakan lembar observasi.

\section{DAFTAR PUSTAKA}

Anas Sujono. (2006). Pengantar evaluasi Pendidikan. Jakarta: PT. Raya Grafindo Persada.

(2008). Pengembangan perangkat penilaian kognitif. Jakarta: Depdiknas.

(2008). Pengembangan perangkat penilaian afektif. Jakarta: Depdiknas.

(2008). Pengembangan perangkat penilaian psikomotor. Jakarta: Depdiknas.

Purwanto. (2010). Metodologi penelitian kuantitatif. Yogyakarta: Pustaka Pelajar. 
Slameto. (2001). Evaluasi pendidikan. Jakarta: Bumi Aksara.

Sugiyono. (2006). Metodologi penelitian pendidikan. Bandung: Alfabeta.

Suharsimi Arikunto. (2002). Prosedur penelitian suatu pendekatan praktek. Jakarta: Rineka Cipta.

Sukardi. (2010). Evaluasi pendidikan. Jakarta: PT. Bumi Aksara. 